Military Technical College

Kobry El-Kobbah,

Cairo, Egypt

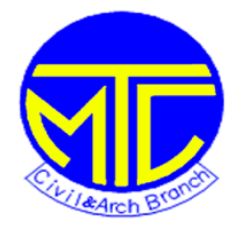

$11^{\text {th }}$ International Conference on Civil and Architecture Engineering

ICCAE-11-2016

\title{
Effect of Grand Ethiopian Renaissance Dam (GERD) on the Life Span of Aswan Reservoir
}

\author{
Osama M. Moussa*, Ahmed S. Elsharkawy * \\ * M. T. C., Egypt
}

\begin{abstract}
About 98 percent of the annual sediments are carried by the Nile during the flood season. Most of these sediments are eroded from the Blue Nile high lands (about 82\%). Since the grand Ethiopian renaissance dam (GERD) start to store the flooding water and sediment during this year, then sediment that will be stored by this dam will effect strongly on the life span of Aswan high dam reservoir (AHDR). The objective of this research is to determine the life span of AHDR with respect to the new regulation of the Nile Basin's water and sediment discharge, after the construction of GERD.

Volume of sediment for the Blue Nile basin was determined by using remote sensing techniques and by the aid of hydrological model, watershed storm hydrograph model (WASHMO) that was established by Andy Ward 1986. Hydrological parameters for 15 sub basin were extracted from digital elevation model (DEM) of Shuttle Topographic Radar Mission. Other parameters that concerns rainfall, soil characteristics and land covers were collected from Atlas of the Blue Nile Basin (Yilma and Awulachew, 2009) and inserted in the mentioned model in order to determine sediment yield from the Blue Nile Watershed.

Life Span of Aswan High Dam Reservoir (AHDR) was studied by many researchers during the last three decades of the last century. There results obtained on the basis of different studies and according to many approaches. It ranges from 362 years to 365 years (Shalash,1980, Makary;1982 and Moussa;1985). According to the volume of sediment that will be retained by grand Ethiopian renaissance dam and found to be $57.50 \times 106 \mathrm{~m} 3$ for one storm/year .Then the life span of Aswan Reservoir can be estimated according to the establishment of this dam.
\end{abstract}

Keyword: Hydrological model, Sediment yield, Life span

\section{Introduction}

Grand Ethiopian Renaissance Dam (GERD) or Taehige, formerly known as the Millennium Dam and sometimes referred to as Hidase Dam, is a gravity dam on the Blue Nile River in Ethiopia currently under construction. It is in the Benishangul-Gumuz region of Ethiopia, about $40 \mathrm{~km}$ (25 mi) east of the border with Sudan. The dam is of a $170 \mathrm{~m}$ (558 ft) height; 1,800 m (5,906 ft) long gravity-type composed of roller-compacted concrete. The dam's reservoir will have a volume of 63 billion cubic meters (51 million acre feet). 
Most of the mathematical models were based on the Universal Soil Loss Equation (USLE). The new version of the USLE (WASHED model) which is modified by Ward 1986 was used to determine the water inflow and sediment yield from 15 small catchment of the Blue Nile watershed. Based on data analysis that been done by Shalash (1980) for life span of AHDR and volume of sediment which resulted from WAHMO model for the Grand Ethiopian Renaissance Reservoir a new value of life span for AHDR was determined.

\section{Study areas}

\subsection{Blue Nile Watershed -Grand Ethiopian Renaissance Reservoir ( GERR )}

The Blue Nile watershed is located in the Eastern region of the African continent (extended from $7^{\circ} \quad 30^{`} \mathrm{~N}$ to $13^{\circ} \quad 00^{`} \mathrm{~N}$ and from $34^{\circ} \quad 00^{`} \mathrm{E}$ to $40^{\circ} \quad 00^{`} \mathrm{E}$ ). This area covers most of the Ethiopian plateau highlands at an elevation of 2000 to 3000 meters above mean sea level, see Figure 1.

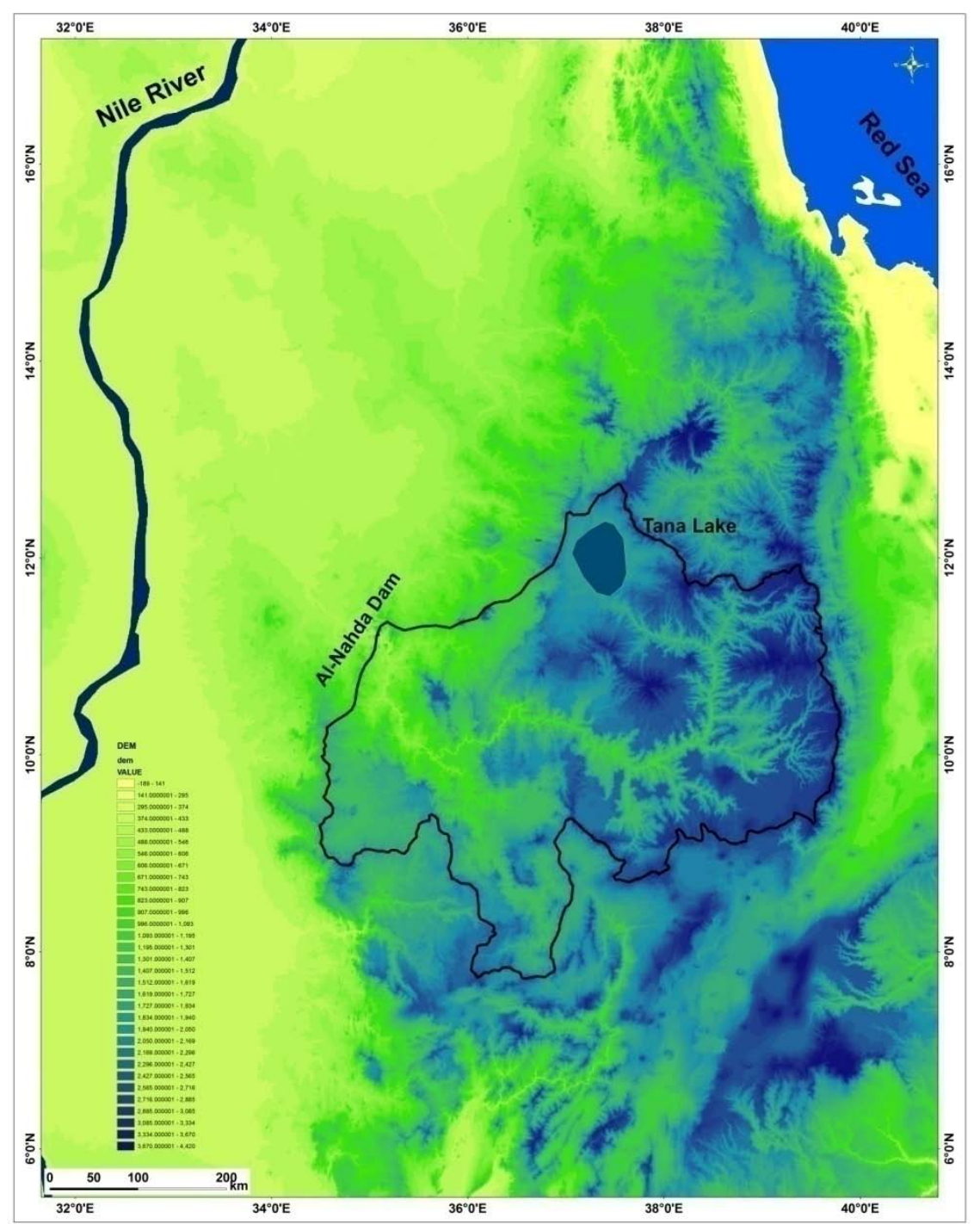

Figure 1: Location of the Blue Nile Watershed.

Source: Ashour S.A., et al. (2014) 


\subsubsection{Topography}

The Blue Nile and its tributaries all rise on the Northern Ethiopian Highland, or plateau, at heights of 2000 to 3000 meters above Mean Sea Level. Most of the Northern Ethiopian plateau is hilly with grassy downs, swamps valleys, and scattered trees. The highest point in this plateau is the peak of Simien Mountains, $4620 \mathrm{~m}$ above sea level(Hurst,1950). Huffnagle (1961) describes the Northern Ethiopian plateau with respect to its topographic variation. This variation ranges from hilly and mountainous to broad rolling and nearly level plains. The Ethiopian plateau is cut up by the deep ravines or canyons in which the rivers flow. In some places the Blue Nile flows into a channel that is about $1300 \mathrm{~m}$ below the level of this plateau on either side.

The Blue Nile Basin, including Lake Tana and its Basin, has an area of 324530 square $\mathrm{km}$. The source of the Blue Nile is a small spring at a height of $2900 \mathrm{~m}$ and at about $100 \mathrm{Km}$ South of lake Tana. From this spring the little Abbai flows down to lake Tana, 1829m above Mean Sea Level. Lake Tana is described by Shahin (1985) as a freshwater body which is situated in Norh-central Ethiopia. Its maximum length is 78 $\mathrm{Km}$, width $67 \mathrm{Km}$ and depth $14 \mathrm{~m}$. Relatively important feeders to lake Tana other than the little Abbai are the Rivers: Reb, Gumara, Magetch, Gelda and Unfraz.

\subsubsection{Rainfall}

The Abyssinian Plateau's climate varies with latitude, altitude and exposure or slope. The rainy season is extended from June until September (Hurst et al., 1931). The West of Ethiopia receives higher amount of rainfall than does the remainder of the country. Highland rainfall normally peaks in August in the administrative regions of Welo and Northern part of Shewa (Figure 1). Rains decreases over much of the highlands during September ( Henricksen, 1986 ).

\subsubsection{Soil Types}

The composition of the volcanic materials, particularly in the Ethiopian North Central Highlands, which cover most of the study area have a major importance for engineers and hydrologists. This is due to severe erosion which is caused by continuous events of storms during the rainy season. Two main soil types had been distinguished by Huffnagle (1961) : the red to reddish brown clayey loams and black soils. The red soils bare the specific latosols characteristics and they have an excellent permeability. The black soils which are derived from disintegration of dolerites are found in the lower parts (depressions) of the study area. This soil type has tendency to dry out quickly and to crack. In wide deep valleys the black soil may have been intermingled with alluvial material (Huffnagle, 1961).

The soil's structure for different soil types in the Blue Nile Basin varies from fine granular ( Cambisols dystric) to medium or coarse granular ( Cambisols humic, Cambisols eutric, arenosols cambic and nitosols eutric). The corresponding permeability classes are slow to moderate for the fine granular and very slow for the medium or course granular. 


\subsubsection{Soil Erodibility Factor, $K$.}

Direct measurement of the soil erodibility factor, $\mathrm{K}$, is costly as well as time consuming. To achieve a better determination of soil erodibility factor for different soil types, the use of field-plot rainfall simulators had been recommended by Wishmeier and Smith (1978) in at least 12 different stations to obtain comparative data on numerous soils. The value of $\mathrm{K}$ is varied from a specific kind of soil to another according to the different properties of soil itself. Silt fraction content, percent of sand in soil, soil structure, organic matter content and permeability class are the most common properties that have been used to determine such factor either from empirical equations, tables or from soil erodibility nomographs.

Values of soil erodibility factors for different soil types vary during the year. Dickinson et al., (1982) determined the variation of K from season to season due to the change of the shear values for surface soils. The plant coverage strongly affects some of soil properties such as, infiltration and organic matter content. It increase infiltration as plant roots open up the soil and increases the organic content of the soil (Mogran,1980).

\subsubsection{Vegetation}

The study area land cover includes agricultural crops, coffee forests, grazing grounds, closed forests, open woodlands, open brush and scrub, as well as lakes and rivers. The important resources for the study area are fertile and climatic conditions which are favorable for cultivating a variety of crops and raising livestock. The cultivated area in Ethiopia are mostly on the highlands, in low valleys and on river plains which have sufficient rainfall or allow a form of irrigation ( Huffnagle, 1961).

\subsection{Aswan High Dam Reservoir}

Aswan high dam reservoir is located in the south of Egypt and extends to the North of Soudan. In may 1964 partial water storage started from flood year construction period until full control on water regulation took place during flood of the year 1968. Project construction was completed in 1969.

River Nile like any other large river has two hydrological phenomena: high muddy and short flow season (3months). Low clear and long flow season (9months). Mud-high concentration of suspended solids has formed the Nile valley of Egypt in the middle of north eastern desert of Africa being later deposited as rich alluvial soil.

The suspended load in the Nile was estimated as average rate of $1 \mathrm{mms}$ annually. The hydrological department of Egypt has confirmed this and the annual rate of suspended sediment (SS) is equal to $0.99 \mathrm{mms}$. And this represents $7 \%$ of the annual avg. of ss. which equals to 134 million tons per. year. The main sources of these SS are Atbara and the Blue Nile rivers.

Before construction of Aswan High Dam all SS were passing carried by flood along the river. Many problems accompanied these SS: 
1-time req. to fill old Aswan reservoir in order to avoid silting as its capacity is limited.

2-all irrigation system of Egypt are effected by deposition of SS. 3-main river regime is affected by dangerous degradation and training works were always required.

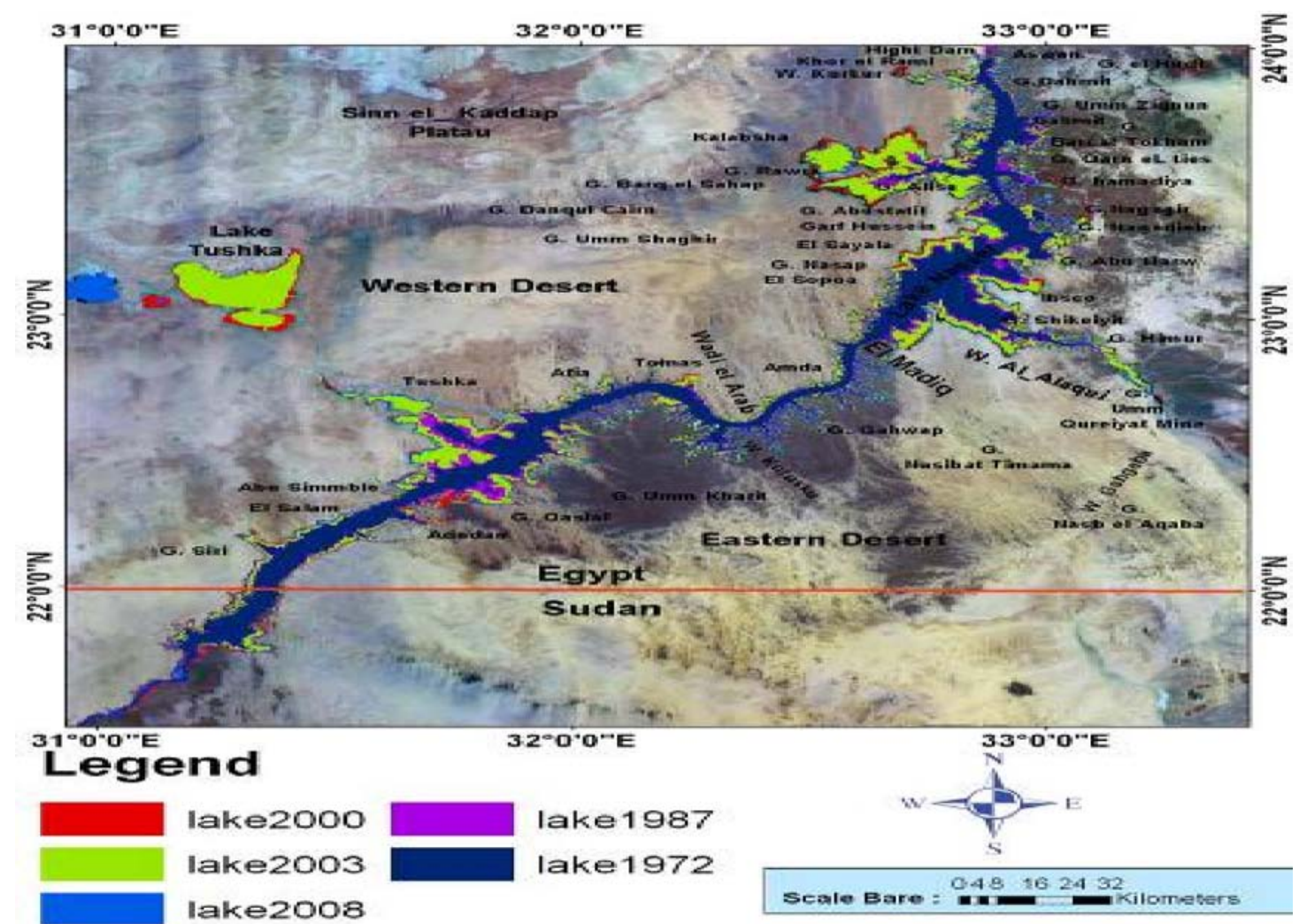

Figure 2 Aswan High Dam Reservoir Location

\section{Model Description}

The WASHMO (Watershed Storm Hydrograph Multiple Option) model was developed by Ward et al., (1979) at the University of Kentucky, Department of Agricultural Engineering. WASHMO had been used to determine volume of water runoff and sediment yield from watershed.

This model consists of two models. The first model describes the hydrology of the watershed and determines a design storm hydrograph. The second model describes the associated detachment, transport and deposition along with sediment yield from the watershed. Detachment occurs when a soil particle is dislodged from the soil surface and/or from the aggregate to which it was attached. When the soil surface is exposed, bare soil, the impact of falling rain drop is sufficient to detach soil particles from the soil mass. As far as the infiltration, percolation and saturation processes take place, and rainfall intensity exceeds the infiltration capacity, some of the excess water may be intercepted as surface storage in depressions, and the remainder becomes surface runoff. The soil particles can be easily transported by water, surface runoff. When the available energy is insufficient to transport soil particles, they will deposit either at a few millimeters of the detachment site or several kilometers downstream in rivers( Ward et al., 1979). 
Sediment yield ( in tons ) was determined by using the modified version of the Universal Soil Loss Equation (USLE) which developed by Hann and Barfield (1978). This modified equation was written in the form :

$\mathrm{Y}_{\mathrm{s}}=95\left(\mathrm{Q} \mathrm{q}_{\mathrm{p}}\right)^{0.56} \mathrm{KL}_{\mathrm{s}} \mathrm{S}_{\mathrm{f}} \mathrm{C} \mathrm{P} \mathrm{r}$

Where $Y_{\mathrm{s}}$ is the sediment yield in tons from a storm, $\mathrm{Q}$ is the volume of runoff in acre- $\mathrm{ft}, \mathrm{q}_{\mathrm{p}}$ is the peak runoff rate in cfs, $\mathrm{K}$ is the soil erodibility factor, $\mathrm{L}_{\mathrm{s}}$ is the slope - length factor, $\mathrm{C}$ is the ground cover factor and $\mathrm{P}_{\mathrm{r}}$ is the reclamation practice factor.

\section{Data Acquisition for BNW}

Data preparation consists of creating main streams and tributaries from digital elevation model (DEM) with the aid of Arc-Map software. The other parameters such as Soil Conservation Factor Curve Number (SCS-CN), soil erodibility factor (K), Conservation Practice factor ( CP ) were collected from other sources and they will be discussed in the following subtitle.

\subsection{Digital Elevation Model}

A 30 m resolution of Digital Elevation Model (DEM) provided by Shuttle Radar Topography Mission (STRM) for the study area is used to describe the elevation of the Blue Nile watershed as shown in Figure 3.

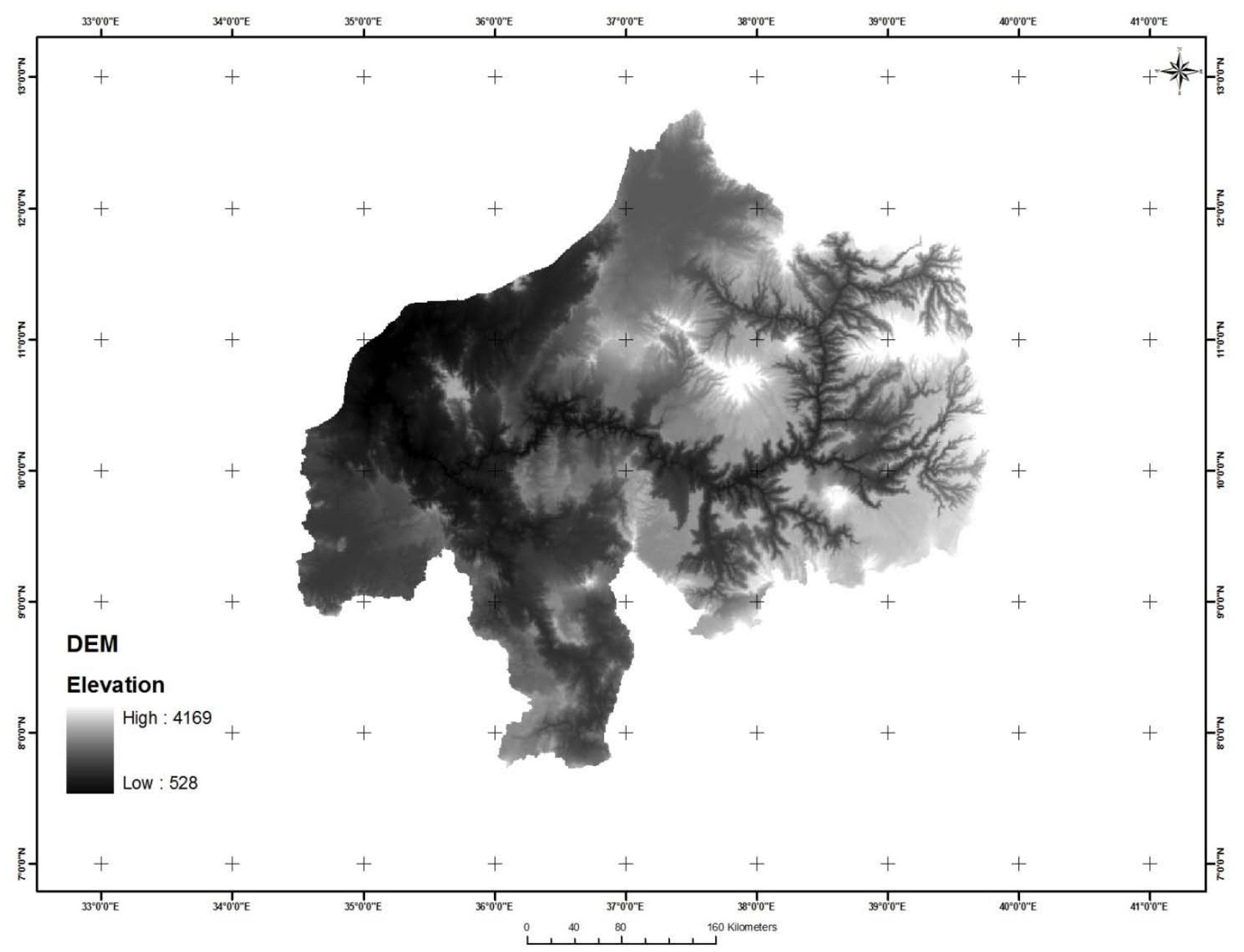

Figure (3) Digital Elevation Model for the study area. 


\subsection{Sub-watersheds extraction}

Main stream and tributaries were extracted from DEM by using Arc-Map software. Fifteen sub-watersheds had been determined from both DEM and the drainage pattern of each catchment as shown in Figure 4.

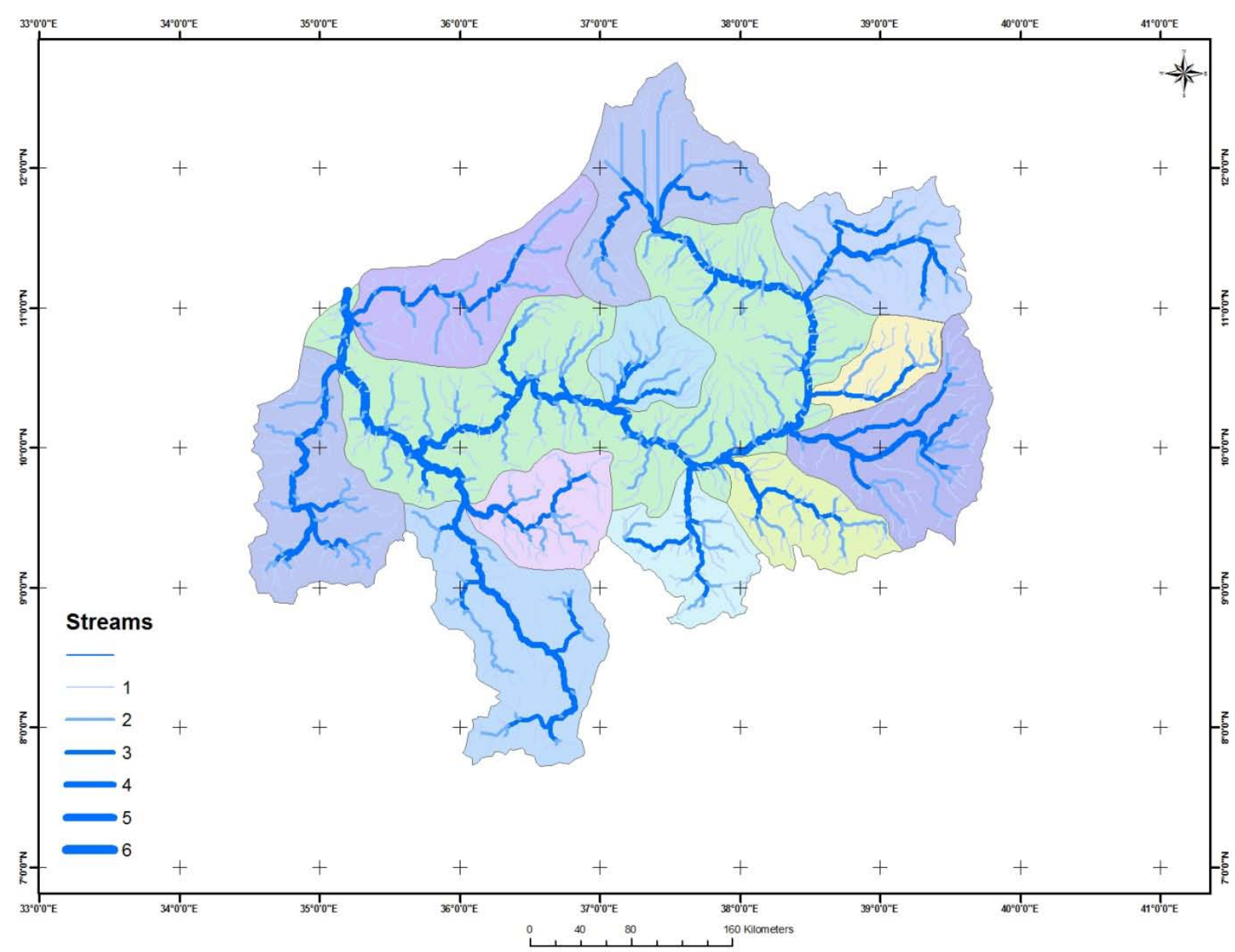

Figure 4: Sub-watersheds of study area.

\subsection{Hydrological Parameters}

The area of the watershed and its 15 sub-watersheds, the lengths of main streams and their slopes and overland flow lengths and their mean slopes were extracted from the Arc-Map software. These values were tabulated in Table 1. 
Table 1: Hydrological parameters that been extracted from Arc-Map Software.

\begin{tabular}{|c|c|c|c|c|c|c|}
\hline $\begin{array}{l}\text { Sub- } \\
\text { watershed }\end{array}$ & Area (ha) & $\begin{array}{l}\text { Channel } \\
\text { length (m) }\end{array}$ & $\begin{array}{l}\text { Channel } \\
\text { slope \% }\end{array}$ & $\begin{array}{l}\text { Hydraulic } \\
\text { length }\end{array}$ & $\begin{array}{l}\text { Overland } \\
\text { flow length } \\
\text { (m) }\end{array}$ & $\begin{array}{l}\text { Overland } \\
\text { flow slope } \\
\%\end{array}$ \\
\hline \multicolumn{7}{|l|}{ Sub1 } \\
\hline 1-D & 104513.76 & 3164.47 & 3.0 & 37872.99 & 6059.68 & 5.0 \\
\hline 2-D & 55820.35 & 35876.13 & 2.0 & 20123.80 & 3219.81 & 6.0 \\
\hline 3-D & 151746.40 & 56067.86 & 1.0 & 54897.72 & 8783.64 & 5.0 \\
\hline 4-D & 82055.77 & 69983.41 & 2.5 & 35699.26 & 5711.94 & 5.0 \\
\hline 5-D & 51792.10 & 81059.04 & 2.0 & 18513.89 & 2962.22 & 7.0 \\
\hline 6-D & 71269.44 & 91619.43 & 2.0 & 39442.64 & 6310.82 & 10.0 \\
\hline 7-D & 44709.40 & 112865.99 & 1.5 & 31956.59 & 5113.05 & 5.0 \\
\hline $1-U$ & 24892.66 & 16349.75 & 2.0 & 13603.69 & 2176.59 & 2.5 \\
\hline $2-U$ & 35944.59 & 29210.47 & 2.0 & 17507.70 & 2801.23 & 2.5 \\
\hline $3-U$ & 38334.99 & 63553.05 & 2.0 & 26402.42 & 4224.39 & 2.5 \\
\hline \multicolumn{7}{|l|}{ Sub2 } \\
\hline 1-L & 471440.72 & 24281.20 & 1.0 & 115550.85 & 43909.32 & 1.3 \\
\hline $1-\mathrm{R}$ & 254946.88 & 24281.20 & 3.0 & 68179.43 & 25908.18 & 2.0 \\
\hline $2-R$ & 159950.47 & 24281.20 & 2.8 & 47371.42 & 18001.14 & 2.0 \\
\hline \multicolumn{7}{|l|}{ Sub-3 } \\
\hline 1-D & 76906.10 & 11014.78 & 3.5 & 43048.94 & 13323.63 & 7.0 \\
\hline 2-D & 79444.03 & 16248.32 & 2.9 & 45439.54 & 14086.26 & 5.7 \\
\hline 3-D & 84505.20 & 43349.14 & 5.9 & 27287.87 & 8459.23 & 13.0 \\
\hline 4-D & 102123.36 & 72904.45 & 3.0 & 49625.29 & 15383.84 & 7.8 \\
\hline $1-U$ & 82409.90 & 6923.29 & 4.1 & 29541.74 & 9157.94 & 5.5 \\
\hline $2-U$ & 103510.38 & 21704.99 & 3.2 & 37591.225 & 11653.28 & 6.0 \\
\hline $3-\mathrm{U}$ & 301648.30 & 273323.96 & 2.75 & 102027.66 & 31628.57 & 7.3 \\
\hline $4-U$ & 97106.46 & 63289.34 & 3.6 & 33003.03 & 10230.94 & 6.8 \\
\hline \multicolumn{7}{|l|}{ Sub-4 } \\
\hline $1-U$ & 290197.95 & 21725.28 & 1.3 & 141470.30 & 58002.70 & 1.7 \\
\hline $1-\mathrm{R}$ & 453955.36 & 70591.95 & 2.6 & 46968.94 & 19257.26 & 5.2 \\
\hline 1-D & 342285.14 & 32679.21 & 5.0 & 40247.59 & 16501.51 & 7.3 \\
\hline
\end{tabular}


Cont. Table 1: Hydrological parameters that been extracted from Arc-Map Software.

\begin{tabular}{|c|c|c|c|c|c|c|}
\hline $\begin{array}{l}\text { Sub- } \\
\text { watershed }\end{array}$ & Area (ha) & $\begin{array}{l}\text { Channel } \\
\text { length (m) }\end{array}$ & $\begin{array}{l}\text { Channel } \\
\text { slope \% }\end{array}$ & $\begin{array}{l}\text { Hydraulic } \\
\text { length }\end{array}$ & $\begin{array}{l}\text { Overland } \\
\text { flow length } \\
\text { (m) }\end{array}$ & $\begin{array}{l}\text { Overland } \\
\text { flow slope } \\
\%\end{array}$ \\
\hline \multicolumn{7}{|l|}{ Sub-5 } \\
\hline 1-D & 158238.80 & 25457.73 & 4.2 & 30628.42 & 5513.12 & 7.3 \\
\hline 2-D & 67654.33 & 43470.85 & 7.9 & 19037.11 & 3426.68 & 15.0 \\
\hline $3-\mathrm{D}$ & 65072.10 & 57082.12 & 11.8 & 10142.39 & 1825.63 & 15.0 \\
\hline 4-D & 77230.69 & 68036.04 & 3.6 & 30507.68 & 5491.38 & 5.5 \\
\hline $1-U$ & 56749.95 & 13692.41 & 9.7 & 15414.83 & 2774.66 & 15.0 \\
\hline $2-\mathrm{U}$ & 45122.56 & 62559.08 & 10.3 & 9739.92 & 1753.18 & 17.0 \\
\hline \multicolumn{7}{|l|}{ Sub-6 } \\
\hline 1-L & 245695.10 & 29453.89 & 1.3 & 91120.56 & 33714.60 & 1.2 \\
\hline $1-\mathrm{R}$ & 200631.60 & 22678.68 & 5.3 & 26362.18 & 9754.00 & 6.1 \\
\hline $2-\mathrm{R}$ & 98936.15 & 55581.02 & 8.5 & 9377.69 & 3469.74 & 11.5 \\
\hline \multicolumn{7}{|l|}{ Sub-7\&8 } \\
\hline 1-U-L & 67624.80 & 6572.35 & 1.0 & 35699.62 & 5247.84 & 6.7 \\
\hline 2-U-L & 107671.45 & 47418.32 & 2.3 & 41857.50 & 6153.05 & 4.9 \\
\hline 3-U-L & 357586.68 & 75350.83 & 0.5 & 125129.78 & 18394.07 & 1.6 \\
\hline 1-U-R & 809402.48 & 35843.68 & 1.0 & 152377.39 & 22399.47 & 1.0 \\
\hline 2-U-R & 305410.95 & 124144.50 & 1.3 & 75665.48 & 11122.825 & 5.4 \\
\hline 3-U-R & 99423.10 & 164673.99 & 1.0 & 29944.21 & 4401.80 & 6.8 \\
\hline \multicolumn{7}{|l|}{ Sub-9 } \\
\hline 1-U-L & 72169.53 & 14199.53 & 1.4 & 50792.47 & 7857.595 & 1.0 \\
\hline 2-U-L & 50198.48 & 41219.2 & 1.1 & 35860.51 & 5547.62 & 1.0 \\
\hline 3-U-L & 49180.34 & 63390.77 & 1.0 & 22498.41 & 3480.504 & 3.0 \\
\hline 1-U-R & 28006.1 & 28338.2 & 1.8 & 21693.45 & 3355.976 & 6.0 \\
\hline 2-U-R & 194581.8 & 83040.89 & 1.0 & 91241.3 & 14115.03 & 1.4 \\
\hline 3-U-R & 316182.53 & 89883.04 & 0.5 & 100095.77 & 15484.8 & 1.3 \\
\hline \multicolumn{7}{|l|}{ Sub-10 } \\
\hline 1-L & 118811.9 & 13306.99 & 3.9 & 74015.33 & 27989.64 & 2.5 \\
\hline $1-\mathrm{R}$ & 41935.35 & 51077.74 & 2.9 & 37551.01 & 14200.29 & 4.2 \\
\hline
\end{tabular}


Cont. Table 1: Hydrological parameters that been extracted from Arc-Map Software.

\begin{tabular}{|c|c|c|c|c|c|c|}
\hline Sub-watershed & Area (ha) & $\begin{array}{l}\text { Channel length } \\
\text { (m) }\end{array}$ & $\begin{array}{l}\text { Channel slope } \\
\%\end{array}$ & $\begin{array}{l}\text { Hydraulic } \\
\text { length }\end{array}$ & $\begin{array}{l}\text { Overland flow } \\
\text { length (m) }\end{array}$ & $\begin{array}{l}\text { Overland flow } \\
\text { slope \% }\end{array}$ \\
\hline \multicolumn{7}{|l|}{ Sub-11 } \\
\hline 1-U-L & 28876.66 & 27181.96 & 2.6 & 30386.96 & 6872.38 & 2.6 \\
\hline 2-U-L & 67447.7 & 16775.73 & 1.1 & 53006.08 & 11987.98 & 3.3 \\
\hline 3-U-L & 63080.1 & 8621.144 & 1.0 & 42823.44 & 9685.05 & 1.5 \\
\hline 1-U-R & 234277.6 & 4564.14 & 2.3 & 88303.23 & 19970.86 & 3.0 \\
\hline \multicolumn{7}{|l|}{ Sub-12 } \\
\hline $1-\mathrm{D}$ & 62844.01 & 61625.97 & 2.40 & 41133.04 & 9837.65 & 4.10 \\
\hline $2-\mathrm{D}$ & 153797.40 & 40022.40 & 2.90 & 47210.43 & 11291.2 & 5.30 \\
\hline 3-D & 66503.40 & 21988.99 & 4.60 & 47089.7 & 11262.3 & 5.30 \\
\hline 1-U-L & 66695.21 & 44059.12 & 2.20 & 35578.9 & 8509.3 & 4.70 \\
\hline 2-U-L & 102211.89 & 29494.5 & 3.10 & 62786.25 & 15016.4 & 4.00 \\
\hline \multicolumn{7}{|l|}{ Sub-13 } \\
\hline 1-U-L & 96132.6 & 14929.8 & 3.80 & 56749.11 & 10316.99 & 5.80 \\
\hline 2-U-L & 59450.22 & 9270.30 & 5.60 & 27770.84 & 5048.74 & 11.80 \\
\hline $1-\mathrm{R}$ & 77968.5 & 11643.62 & 2.70 & 59083.50 & 10741.38 & 3.70 \\
\hline \multicolumn{7}{|l|}{ Sub-14 } \\
\hline $1-\mathrm{D}$ & 180357.43 & 26613.98 & 1.00 & 50510.73 & 18264.68 & 1.00 \\
\hline $1-\mathrm{U}$ & 49475.45 & 29109.04 & 4.30 & 28133.10 & 10172.92 & 9.80 \\
\hline $2-U$ & 128196.46 & 33855.74 & 2.80 & 79529.25 & 28757.78 & 2.80 \\
\hline $3-U$ & 150949.56 & 87953.67 & 2.80 & 77597.4 & 28059.21 & 2.90 \\
\hline \multicolumn{7}{|l|}{ Sub-15 } \\
\hline 1-D & 106579.54 & 41117.78 & 1.00 & 49263.10 & 11783.72 & 1.00 \\
\hline $2-\mathrm{D}$ & 93624.14 & 100289.26 & 2.80 & 49947.27 & 11947.4 & 3.30 \\
\hline $3-\mathrm{D}$ & 89049.91 & 132846.76 & 2.30 & 53207.32 & 12727.2 & 2.40 \\
\hline $4-\mathrm{D}$ & 69351.22 & 150210.76 & 2.30 & 39764.63 & 9511.7 & 5.30 \\
\hline $1-\mathrm{U}$ & 158209.31 & 37385.34 & 2.70 & 59566.44 & 14248.3 & 2.10 \\
\hline $2-U$ & 102182.4 & 62761.93 & 2.30 & 60009.2 & 14354.2 & 2.30 \\
\hline $3-U$ & 143483.24 & 29192.82 & 1.90 & 46727.46 & 111177.21 & 3.60 \\
\hline $4-\mathrm{U}$ & 82395.15 & 111121.48 & 3.00 & 32801.79 & 7846.2 & 2.50 \\
\hline $5-U$ & 234776.03 & 118221.24 & 1.60 & 112733.51 & 26965.86 & 1.50 \\
\hline 6-U & 206032.14 & 146295.75 & 1.90 & 84922.43 & 20313.45 & 1.50 \\
\hline
\end{tabular}


Table 2 : Land Cover and SCS (CN) for each Sub-Basin

\begin{tabular}{|c|c|c|c|c|}
\hline \multirow[t]{2}{*}{ Sub Basin } & \multicolumn{3}{|c|}{ Land Cover } & \multirow{2}{*}{$\begin{array}{l}\text { Soil Concervation } \\
\text { service curve } \\
\text { number (CN ) }\end{array}$} \\
\hline & Agriculture & Forest & Grassland & \\
\hline Sub(1) & 40 & 50 & 10 & 57 \\
\hline Sub(2) & 60 & 1 & 5 & 62 \\
\hline Sub(3) & 90 & 0 & 1 & 57 \\
\hline Sub(4) & 40 & 6 & 40 & 56 \\
\hline Sub(5) & 54 & 6 & 40 & 58 \\
\hline Sub(6) & 55 & 5 & 35 & 63 \\
\hline Sub(8) & 40 & 45 & 5 & 54 \\
\hline Sub(9) & 20 & 55 & 25 & 52 \\
\hline Sub(10) & 80 & 0 & 15 & 61 \\
\hline Sub(11) & 40 & 10 & 50 & 63 \\
\hline Sub(12) & 41 & 0 & 59 & 61 \\
\hline Sub(13) & 10 & 5 & 80 & 62 \\
\hline Sub(14) & 70 & 0 & 30 & 60 \\
\hline 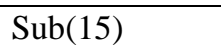 & 5 & 90 & 3 & 53 \\
\hline
\end{tabular}

\subsection{Soil Conservation Service Curve Number}

Regarding to the land use and soil characteristics for the study area, Soil Conservation Service - Curve Number (SCS-CN) which represents the runoff potential of an area for each sub-watershed was determined by using Hann and Barfield (1978) approaches, see tables 2 and 3. The hydrologic soil groups that are given in Table 3 are based on the infiltration rate, depth, drainage and texture of different types of soil. The weighted mean value of the $\mathrm{CN}$ was used as a combined value for different kinds of vegetation coverage in each small catchment, when more than one type occurred. $\mathrm{CN}$ was found to be 42 . The vegetation coverage percentage for each catchment was determined from Atlas of Ethiopia. The description of different types of land cover was discussed widely by Huffnagel (1961). 
Table 3: Definition of SCS hydrologic soil groups.

\begin{tabular}{|c|l|}
\hline Soil Type & \multicolumn{1}{c|}{ Description } \\
\hline A & $\begin{array}{l}\text { These soils with high infiltration rate are chiefly deep, well-drained sands or gravel } \\
\text { (Low runoff potential). }\end{array}$ \\
\hline B & $\begin{array}{l}\text { These soils with a moderate infiltration rate when thoroughly wet, are chiefly } \\
\text { moderately deep, well-drained soils of moderately fine to moderately coarse texture. }\end{array}$ \\
\hline C & $\begin{array}{l}\text { These soils with a slow infiltration rate when wet are chiefly moderated deep, well- } \\
\text { drained soils of moderately fine to moderately coarse texture. }\end{array}$ \\
\hline D & $\begin{array}{l}\text { These soils with a very slow infiltration rate, are chiefly clay soils with a high } \\
\text { swelling potential, soils with a permanently high water table , soils with a clay pan } \\
\text { at or near the surface and shallow soils over nearly impervious materials (high } \\
\text { runoff potential). }\end{array}$ \\
\hline
\end{tabular}

Table 4: Runoff Curve Number for Selected Agriculture.

(Antecedent Rainfall $=1.4-2.1$ inches).

\begin{tabular}{|l|c|c|c|c|}
\hline \multirow{2}{*}{ Land use description } & \multicolumn{4}{c|}{ Hydrological soil group } \\
\cline { 2 - 5 } & A & B & C & D \\
\cline { 2 - 5 } & 72 & 81 & 88 & 91 \\
\hline Cultivated Land: & 62 & 71 & 78 & 81 \\
* Without conservation treatment. & 68 & 79 & 86 & 89 \\
\hline With conservation treatment. & 39 & 61 & 74 & 80 \\
* Poor condition. & 30 & 58 & 71 & 78 \\
** Good condition. & 45 & 66 & 77 & 83 \\
\hline Meadow: good condition. & 25 & 55 & 70 & 77 \\
\hline Wood or forest land: & & & & \\
* Thin stand, poor cover, no mulch & ** Good cover &
\end{tabular}




\subsection{Soil Erodibility Factor}

The soil erodibility factor, $\mathrm{K}$, was found to be 0.20 . This factor was determined by using soil erodibility nomograph given by Wischmeier and smith (1978). Percentage of agriculture, forest, and grass land coverage for the each Sub-Watershed was tabulated in table 1. The maximum rainfall amount was extracted from the Jemma station and found to be $287 \mathrm{~mm}$ and the time duration was assumed to be 24 hours. Sieve analysis of soil samples was studied and the particle size distribution of sediment flow was found to be as follows:

\begin{tabular}{|l|c|c|c|c|c|}
\hline Particle size (mm) & 0 & 0.002 & 0.05 & 0.1 & 2.0 \\
\hline \% Finer & 0 & 48.1 & 77 & 82 & 100 \\
\hline
\end{tabular}

Conservation Practice factor ( CP ) was found to be 0.05 ( Wischmeier and smith ,1978).

\section{Data Collection for AHDR}

River Nile like any other large river has 2 hydrological phenomena (Shalash,1980):

1) high muddy and short flow season, 3 months, (flood).

2) Low clear and long flow season, 9 months.

Mud-high concentration of suspended solids (SS) has formed the Nile valley of Egypt in the middle of North Eastern desert of Africa, being later deposited as rich alluvial soil.

The main source of the SS is two main tributaries of the Nile, Atbara and Blue Nile Rivers. They bring down during the rainy season (July / September) the eroded surface soil of Ethiopian mountains carried by their flood.

The suspended load in the Nile was estimated by scientists during the eighteen century as average rate of $1 \mathrm{mms}$ annually.

The hydrological department of Egypt has confirmed this and accepts that the annual rate of suspended load is equal to $0.9 \mathrm{mms}$, which represents $7 \%$ of the annual average of suspended load which equal to 134 million tons per year. The rest of SS travels with the flood flow into the Mediterranean Sea.

Dam is of rock fill type with clay core and is reinforced with cement injection to a depth of 200ms. All reservoirs built across river Nile are of seasonal type except AHD reservoir, its main function is to work as an over year storage reservoir.

Data for AHDR were collected from Shalash (1980) as follows:

\subsection{Main Levels of AHDR}

1-average of natural river bed surface and is about $80 \mathrm{~m}$ at the dam site.

2-level of dead storage is $147 \mathrm{~m}$ above Mean Sea Level (M.S.L.)

3-level of full supply storage is $175 \mathrm{~m}$ above M.S.L.

4-level of flood storage is $182 \mathrm{~m}$ above M.S.L. 
5-level of spillway spills are $178 \mathrm{~m}$ above M.S.L.

6-dam crest level is $196 \mathrm{~m}$ above M.S.L.

7-highest contour levels around the reservoir are approximately at the level of $200 \mathrm{~m}$ above M.S.L.

\subsection{Surface area of the Reservoir:}

At level $182 \mathrm{~m}$ surface area is $6540 \mathrm{~km}^{2}$.

At level $180 \mathrm{~m}$ surface area is $6118 \mathrm{~km}^{2}$.

At level $175 \mathrm{~m}$ surface area is $5198 \mathrm{~km}^{2}$.

\subsection{Reservoir capacity:}

at level $182 \mathrm{~m}$ volume is $162.33 \mathrm{~km}^{3}$.

At level $180 \mathrm{~m}$ volume is $149.50 \mathrm{~km}^{3}$.

At level $175 \mathrm{~m}$ volume is $121.30 \mathrm{~km}^{3}$.

At level $147 \mathrm{~m}$ dead storage level volume is $31.6 \mathrm{~km}^{3}$.

\subsection{Reservoir Water Balance}

Before construction of AHD, maximum storage level was $121.3 \mathrm{~m}$ and its capacity $5.10 \mathrm{~km}^{3}$ but after construction live storage was $175 \mathrm{~ms}$ and capacity $121 \mathrm{~km}^{3}$ of stored water.

The lake started to fill up from the flood season of the year 1964. Water years during the period 1964/65 and 1983/84 varied between high, normal and low water years. General behavior of water balance of AHD lake is similar to any other lake and follows the general water balance:

inflow $=$ out-flow \pm contents + general losses

in order to apply this rule for water general condition of the lake must be considered: 1 -formation of most banks of the lake are fine to medium sandy soils and river bed is of alluvial kind.

2-climate of area is dry, hot and of low relative humidity.

3-reservoir was filled for the first time until 1979.

4-water levels have not yet reached its max. flood levels $182 \mathrm{~m}$.

5-surface water management of had is based on long term storage reservoir.

6-area of lake and its capacity are large also of long shape with many wings.

\subsection{Results of Reservoir Balance}

1-Partial control of Nile flow , started in the year 1964/65 and full control of flow started from the year 1968/69.

2-Reservoir area is covered with water for first time and lake reached its max. levels by the end of the year 1977 during high water years period.

3-Water levels in the lake fluctuated normally during normal water years.

4-Lake water levels started to draw down during recent water years period reached its down due to present low water year1983/84. 


\subsection{General remarks of total period:}

-total river runoff into lake $=1450.98 \mathrm{~km}^{3}$.

-total out flow from had $=1174.48 \mathrm{~km}^{3}$.

-total reservoir capacity at end $=78.42 \mathrm{~km}^{3}$.

-total general losses $=199.08 \mathrm{~km}^{3}$.

\subsection{Different items composing the general losses are as follows}

-total losses by evaporation $=182.78 \mathrm{~km}^{3}$.

-total water losses between gauging $=14.82 \mathrm{~km}^{3}$.

-total water losses through seepage $=55.73 \mathrm{~km}^{3}$.

-total water gains during draw down $=54.20 \mathrm{~km}^{3}$.

\section{Results and Analysis}

\subsection{Life Span of Grand Ethiopian Renaissance Reservoir}

The maximum rainfall at Jemma station $(287 \mathrm{~mm}$ ) with duration 24 Hours gives volume of water $=2633365 \times 10^{3} \mathrm{~m}^{3}$ and sediment volume $=57495094.34 \mathrm{~m}^{3}$.

Since the capacity of GERR was estimated by the Ethiopian Government by the value of $63 \times 10^{9} \mathrm{~m}^{3}$, then the following assumptions will be taken in consideration:

1- The Grand Ethiopian Renaissance dam will retain sediment into GERR.

2- No water losses from evaporation.

3- Effect of permeability is minimum.

4- No consumption of the stored water behind the reservoir for public use or irrigation purposes.

According to the resulted values of water volumes and sediment weight (weight in tones should be converted to volume) and under the mentioned conditions, the required filling time is found to be:

I) In case of filling of water and sediment :

* Since the reservoir capacity is $63 \times 10{ }^{9} \mathrm{~m}^{3}$

*And the total volume of water and sediments for $1 \mathrm{storm}=2.69 \times 10^{9} \mathrm{~m}^{3} / \mathrm{yr}$

*The required filling time of the reservoir is $\left(63 \times 10^{9}\right) /\left(2.69 \times 10^{9}\right)=$ 23.42 years

*The required filling of the reservoir for 4 storm $/$ year $=5.86$ years

II) In case of filling of sediment only, the life span (LS) will be as follows:

*Since the reservoir capacity is $63 \times 10^{9} \mathrm{~m}^{3}$

*And the total volume of sediments $=57495094 \mathrm{~m}^{3} / \mathrm{yr}$

*The estimated life span of the reservoir for one storm/year = $\left(63 X 10^{9}\right) /(57495094)=1095.74$ years

* The estimated life span of the reservoir for 4 storm/year $=$ $\left(63 \times 10^{9}\right) /(4 X 57495094)=273.94$ years

The area of GERR is shown in Figure 5. 


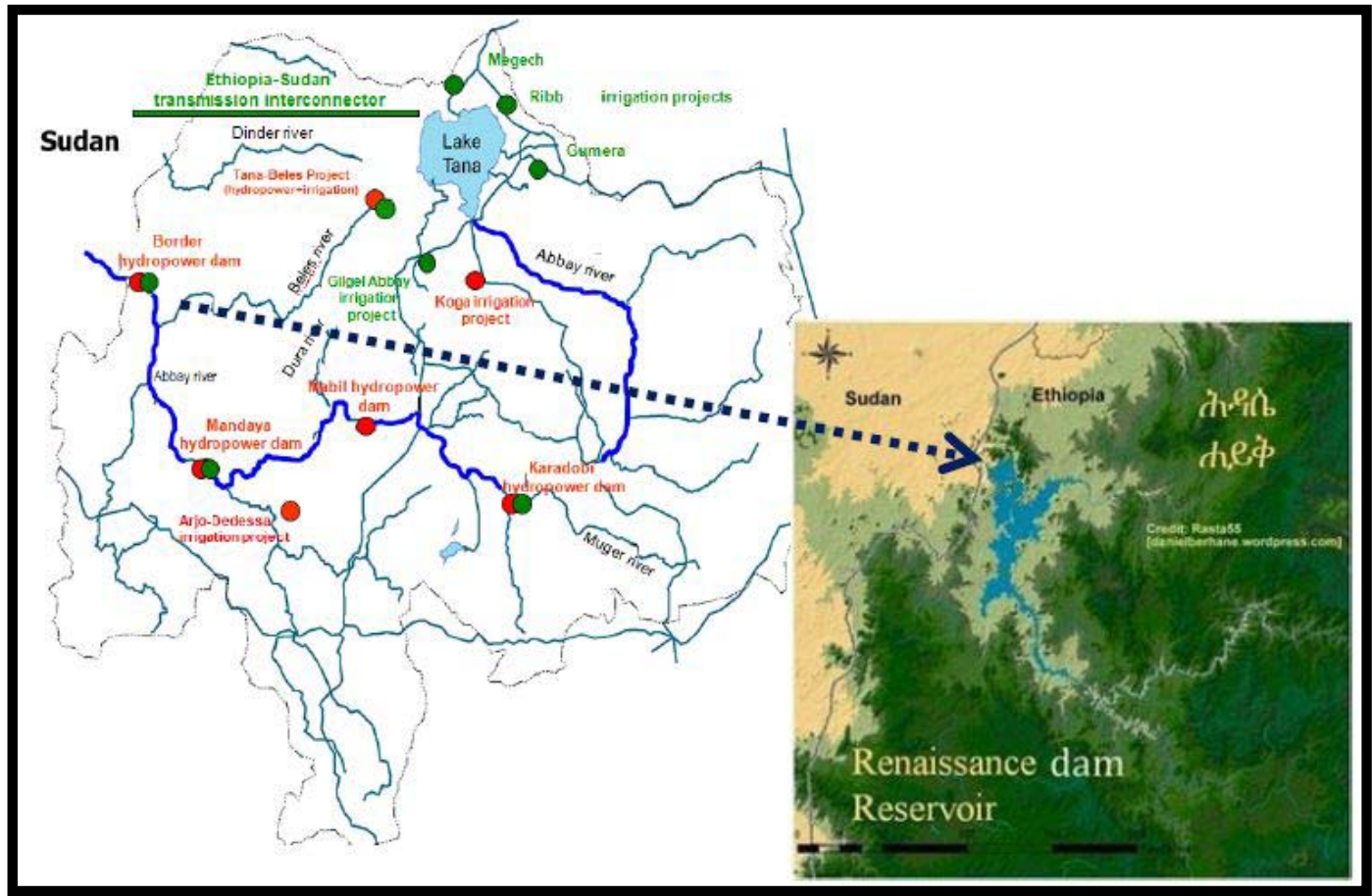

Source: Ana Elisa Cascao,2011. Grand Renaissance Dam in Ethiopia-Stokholm.

Figure 5 The area of Grand Ethiopian Renaissance Reservoir (GERR)

\subsection{Life Span of Aswan High Dam Reservoir}

Designer of AHDR expected that the total load of Suspended Solids(SS) will deposite in the reservoir and fill the dead storage in 400-500 years. Based on field observations, Shalash(1980) was estimate the life span of the AHDR. In order to estimate rate of sediment deposition within the next 100years in AHDR(started from1979) Shalash had considered three assumptions:

1- Assume that the next 100 years run-off of the Nile will be similar to the last 100 years 1869/70 - 1978/79.

2- Estimating of total load of SS by the following equation:

$$
Q_{\mathrm{s}}=0.328 \times \mathbf{Q}_{\mathrm{f}}{ }^{1.49}
$$

Where $\mathbf{Q}_{\mathbf{f}}$ : the total discharge of the Nile during flood season( at El-

$$
\begin{aligned}
& \text { Gaffra discharge station) August to October in } \mathrm{Km}^{3} \text {. } \\
& \mathbf{Q}_{\mathbf{s}} \text { : Total sediment load in } 10^{6} \text { tons and represent } 96 \% \text { of the total annual } \\
& \text { sediment load. }
\end{aligned}
$$

3- Forecasting the total load of SS which will pass in future (500 years).

From recorded data of the run-off of the Nile for the months August to October for the period 1879/80 to 1978/79 and applying the previous equation, values of $\mathbf{Q}_{\mathbf{s}}$ were estimated. 
The following results were observed by Shalash after forecasting the SS load passing AHDR :

*Average rate of inflow Qs $=142 \times 10^{6}$ tons

* Average rate of outflow Qs $=6 \times 10^{6}$ tons

*Therefore the average rate of SS deposition in AHDR is $136 \times 10^{6}$ tons.

Life span of AHDR was estimated by Shalash according to the following data:

- $\quad$ Dead storage capacity $=31.6 \times 10^{9} \mathrm{~m}^{3}$

- Average specific gravity within 500 years $=1.56 \mathrm{t} / \mathrm{m}^{3}$

- Average annual inflow Load $=142 \times 10^{6}$ tons

- Average annual outflow load $=6 \times 10^{6}$ tons

Therefore estimated Life span for AHDR may be 362 years.

\section{Conclusion and Recommendations}

From results that been discussed in the previous sub-titles we conclude that:

- $\quad$ Based on assumptions given in 6.1 \& 6.2.

- $\quad$ And Life span of the Grand Ethiopian Renaissance dam =273.94 years.

- $\quad$ And Life span of the AHDR = 362 years.

And since SS which passed down stream AHD was decreased gradually until it reached $1.0 \%$ (out off $142 \times 10^{6}$ tons) in 1973. Then the life span of AHDR will increase and simply can be calculated based on the following assumptions:

Starting filling of SS in AHDR is the year 1973.

Starting filling of SS in GERR is the year 2016.

Then life span of AHDR $=362-43+274=593$ years

This life span is started from the beginning of filling GERR.

We recommend to use actual rainfall storm event, and the actual number of these events, actual rainfall duration, percentage of evaporation and infiltration for both reservoirs that been neglected in our calculation. Also, we should take in future work the stored water around both reservoirs for public use or irrigation purposes.

\section{Refernces:}

- Dickinson et al., 1982, “ The great Salinity anomaly in the Northern North Atlantic 1968-1982”, Robert R Dickson, Jeno Meincke, Svend-Age Malmberg, Arthur J. Lee.

- Henricksen, B.L., 1986, “Reflections on drought”: Ethiopia 1983-1984, International Journal of Remote Sensing. Vol. 7, No. 11, Nov. 1986, pp. 14471451. 
- Hurst, H.E., 1952 The Nile, A General Account of the River and the Utilization of its Waters, Constable Publisher, London.

- Hurst, H.E.,1950, The Nile Basin. The Hydrology of the Sobat and the Topography of the Blue Nile and Atbara Vol. VIII, Government Press, Cairo, Egypt.

- Hurst, H. E., and Philips P., 1931,” The Nile Basin Vol. V. The hydrology of the Lake Plateau and Bahr el Jabel. Physical Department paper No. 35, Schnidlers Press, Cairo, 235 pp.

- Huffnagle, H.P., 1961. Agriculture in Ethiopia, Food and Agricukture Organization of United Nation, Rome, 1961.

- Murphy H.F.,1986, “A Report on the fertility status and other data on some soils of Ethiopia, Jumma, Ethiopia” , College of Agriculture, Haile Sellassis University, Experiment Station Bulletin No. 44.

- Mutchler and Carter, 1983 , "Seasonal Soil Loss and erodibility variation on a Miamian Silt Loam Soil “.

- Shahin, M.,1985. Hydrology of the Nile Basin, International Institute for Hydraulic and Environmental Eng., Netherlands, Elsevier Science Publisher B.V.

- Ulsaker, L.G. and Onstad,C.A. 1984, "Reality Rainfall Erosivity factors to Soil loss in Kenya”.

- Wishmeier W.H. and Smith, D.D. 1978, “ Predicting rainfall Erosion Losses” , A guide to conservation planning. Science and Education Administration, United States Department of Agriculture Hyattsville, Maryland, pp58.

- Ward, A.D., Hann, C.T. and Tapp, J.S. ,1979, “ The DEPOSITS Sedimentation Pond Design Manual “, Institute for mining and minerals Research Office of Informational Services, University of Kentucky, Lexington, Kentucky.

- Hann, C.T. and Barfield, B.J., 1978. Hydrology and Sedimentology of Surface Mined Lands. Office of Continuing Education and Extension College of Engineering. University of Kentucky, Lexington, Kentucky.

Shalash, S; 1980. Effect of Sedimentation on Storage Capacity of High Aswan Dam Lake, $15^{\text {th }}$ Anniversary of divesion of River Nile 1964-1979 Research Institute of High Dam Side Effects, Ministry of Irrigation- Egypt,May 1980, Paper No. 56. 
- Makary, A.Z., 1982, Sedimentation in the Aswan High Dam Resrvoir, Ph. D. Dissertation, Ain Shams University, Cairo, Egypt.

- Moussa, O.M., 1985, Analysis of Sedimentation in Aswan Reservoir, M Sc thesis, Ohio State University, U.S.A.. 